\title{
Effects of entomopathogenic fungi on different developmental stages of Cotesia flavipes (Cam.) a parasitoid of Diatraea flavipennella (Box) (Lepidoptera: Crambidae)
}

\section{Efeito de fungos entomopatogênicos nas diferentes fases de desenvolvimento do parasitoide Cotesia flavipes (Cam.) em Diatraea flavipennella (Box) (Lepidoptera: Crambidae)}

\author{
Cinthia Conceição Matias da Silva ${ }^{1 *}$; Edmilson Jacinto Marques²; \\ José Vargas de Oliveira ${ }^{2}$; Auristela Correia de Albuquerque ${ }^{3}$; \\ Eliana Maria dos Passos ${ }^{4}$; Jennifer Guimarães ${ }^{5}$
}

\begin{abstract}
Biological control using the parasitoid Cotesia flavipes (Cam.) is one of the main components in the integrated management of the sugarcane moth borer Diatraea spp. Besides this parasitoid, the entomopathogenic fungi Beauveria bassiana (Bals.) Vuill and Metarhizium anisopliae (Metsch.) Sorok. are used to control sugarcane pests, and they can be found naturally parasitizing caterpillars. This study aimed to evaluate the effects of $M$. anisopliae and B. bassiana on different developmental stages of the C. flavipes parasitoid on Diatraea flavipennella (Box). The experiments were carried at laboratory with isolates PL 43 of $M$. anisopliae and ESALQ 447 of $B$. bassiana were applied to the parasitoid at the immature and adult phases. No negative effects were observed on the larval development of $C$. flavipes, and it could complete its development on caterpillars of $D$. flavipennella treated with fungi. The fungi did not cause pupal mortality. However, B. bassiana caused high mortality in the adult parasitoid (76\%). The fungi had negative effects on parasitoids when applied during certain developmental stages of $C$. flavipes. Key words: Sugarcane moth borer, biological control, microbial control, endoparasitoid
\end{abstract}

\section{Resumo}

No manejo integrado das brocas da cana-de-açúcar Diatraea spp, o controle biológico com o parasitoide Cotesia flavipes (Cam.) é um dos principais componentes. Além do parasitoide, os fungos entomopatogênicos Beauveria bassiana (Bals.) Vuill. e Metarhizium anisopliae (Metsch.) Sorok. também são empregados no controle de pragas da cana-de-açúcar, podendo ser encontrados naturalmente parasitando lagartas na cultura. Assim, o objetivo do trabalho foi avaliar o efeito dos fungos $M$. anisopliae e B. bassiana nas diferentes fases de desenvolvimento do parasitoide $C$. flavipes em Diatraea flavipennella (Box). Os experimentos foram conduzidos em condições de laboratório com

${ }^{1}$ Eng $^{\mathrm{a}} \mathrm{Agr}^{\mathrm{a}}$, Discente do Curso de Doutorado em Entomologia Agrícola, Dept ${ }^{\mathrm{o}}$ de Agronomia, Universidade Federal Rural de Pernambuco, UFRPE, Recife, PE, Brasil. E-mail: cinthia_cms@hotmail.com

2 Profs. Drs., Dept ${ }^{\circ}$ de Agronomia, Entomologia, UFRPE, Recife, PE, Brasil. E-mail: emar@depa.ufrpe.br; vargasoliveira@uol. com.br

3 Prof ${ }^{\mathrm{a}}$. Dr ${ }^{\mathrm{a}}$, Dept ${ }^{\mathrm{o}}$ de Biologia, Entomologia, UFRPE, Recife, PE, Brasil. E-mail: auritermes@yahoo.com.br

4 Bióloga, Discente do Curso de Doutorado em Entomologia Agrícola, Dept ${ }^{\circ}$ de Agronomia, UFRPE, Recife, PE, Brasil. E-mail: bisologa@hotmail.com

5 Eng $^{\mathrm{a}}$ Agr $^{\mathrm{a}}$, Discente do Curso de Mestrado em Entomologia Agrícola, Dept ${ }^{\circ}$ de Agronomia, UFRPE, Recife, PE, Brasil. E-mail: je_pituka@hotmail.com

Author for correspondence 
os isolados de M. anisopliae PL-43 e de B. bassiana ESALQ 447, aplicados sobre as fases imatura e adulta do parasitoide. Não foram observados efeitos negativos sobre o desenvolvimento larval de $C$. flavipes, que completou seu desenvolvimento em lagartas de $D$. flavipennella, tratadas com os fungos. Não foi observada mortalidade de pupas, porém, B. bassiana provocou elevada mortalidade nos adultos do parasitoide $(76 \%)$. Foram evidenciados efeitos negativos dos fungos sobre o parasitoide, quando aplicados em determinado período de desenvolvimento de C. flavipes.

Palavras-chave: Broca da cana-de-açúcar, controle biológico, controle microbiano, endo-parasitoide

\section{Introduction}

Sugarcane is one of the main crops in Brazil, and its planting area is expanding every year, occupying approximately 9000 ha (COMPANHIA NACIONAL DE ABASTECIMENTO - CONAB (NATIONAL SUPPLY COMPANY), 2014). Pests are one of the main factors limiting sugarcane production. The species Diatraea flavipennella, known as the borer of yellow head, is considered an important pest causing injuries in sugarcane similar to those caused by Diatraea saccharalis (FREITAS et al., 2007). Its distribution, unlike D. saccharalis (which is widespread in Brazil), is restricted mainly to the northeastern states of the country (FREITAS et al., 2006). According to White et al. (2008), D. saccharalis caterpillars cause losses of sugar/ha up to $0.30 \%$ for each $1 \%$ of internodes that are attacked.

These borers are managed with inundative releases of Cotesia flavipes, a larval endoparasitoid (CAMERON, 1891) (Hymenoptera: Braconidae) (PINTO et al., 2006). Although this braconid is an effective control agent, it has not been effective in controlling D. flavipennella, and entomopathogenic fungi are an alternative to improve the management of this pest. According to Alves et al. (2008), D. saccharalis is susceptible to Metarhizium anisopliae (Metsch.) Sorok. and Beauveria bassiana (Bals.) Vuill., which infect about $10 \%$ of the caterpillars under natural conditions in northeastern Brazil.

Thus, mass release of $C$. flavipes and the application of $M$. anisopliae are commonly done by sugar and ethanol mills in Brazil; however, there is a need to evaluate the effects of the interactions among these biological agents for control optimization (ALVES; LOPES, 2008). Pathogens may or may not harm the natural enemies, depending on factors such as the pathogen species, isolate, concentration, and parasitoid species. However, the effects of pathogens on parasitoids are usually less severe than those of pesticides, which may or may not cause premature death of eggs, larvae, and adults of the parasitoid (ROSSI-ZALAF et al., 2008). This is due to the wide host range of entomopathogenic fungi and the possibility of direct infection on non-target organisms, which should be carefully evaluated before the large-scale use of these microorganisms (MAGALHÃES et al., 1998). Folegatti and Alves (1987) found that C. flavipes parasitizing D. saccharalis caterpillars had its development hampered by $M$. anisopliae.

This study aims to evaluate the effects of $B$. bassiana and $M$. anisopliae on the larval, pupal, and adult stages of $C$. flavipes parasitizing $D$. flavipennella.

\section{Material and Methods}

Effect of fungi on Parasitoid Larvae. Fourth instar D. flavipennella caterpillars were separated and sprayed with $1 \mathrm{~mL}$ of fungal suspension at a concentration of $10^{7}$ conidia $\mathrm{mL}^{-1}$ in every treatment using a micro-atomizer. For parasitism, 24-hour-old adults were kept in plastic containers $(5 \times 7 \mathrm{~cm})$ with a small hole in the lid that allowed adults to exit. Subsequently, caterpillars were placed close to the hole, enabling the deposition of parasitoid eggs. After observing the female parasitoid oviposition behavior and the fungal application, the caterpillars were transferred to plastic pots containing pieces of sugarcane and kept in climatic chambers at 27 $\pm 1{ }^{\circ} \mathrm{C}$ and $70 \pm 10 \%$ relative humidity $(\mathrm{RH})$. The 
control was treated with $\mathrm{ADE}+\mathrm{A}$. The effects of natural enemies were evaluated daily by observing the parasitism and mortality of caterpillars, which were transferred to humid chambers and kept at a temperature of $26 \pm 1{ }^{\circ} \mathrm{C}, 70 \pm 10 \% \mathrm{RH}$ and $12 \mathrm{~h}$ photophase for confirming the causal agent.
The experiment was carried out in a completely randomized design consisting of 10 treatments; for every treatment, 8 replicates of 5 caterpillars were prepared, for a total of 40 caterpillars per treatment (Table 1).

Table 1. Treatments and days after inoculation with C. flavipes and fungi.

\begin{tabular}{cc}
\hline Treatments (Control Agents) & Days after inoculation \\
\hline Metarhizium anisopliae & - \\
Beauveria bassiana & - \\
Cotesia flavipes & - \\
Cotesia flavipes + Metarhizium anisopliae & 1 \\
Cotesia flavipes + Metarhizium anisopliae & 3 \\
Cotesia flavipes + Metarhizium anisopliae & 6 \\
Cotesia flavipes + Beauveria bassiana & 1 \\
Cotesia flavipes + Beauveria bassiana & 3 \\
Cotesia flavipes + Beauveria bassiana & 6 \\
Control & - \\
\hline
\end{tabular}

The evaluated parameters were mortality caused by fungi and parasitoids, sex ratio, number of emerged adults, and egg-adult period. The data were submitted to analysis of variance using the SAS software (SAS, 1999-2001), and the means were compared by a Tukey test $(\mathrm{P} \leq 0.05)$.

\section{Effect of Fungi on Parasitoid Pupae. D.} flavipennella caterpillars in the fourth instar were parasitized by $C$. flavipes and subsequently transferred to plastic pots containing an artificial diet and kept in climatic chambers at $27 \pm 1{ }^{\circ} \mathrm{C}$ and $70 \pm 10 \% \mathrm{RH}$ up to the formation of the parasitoid masses. These masses were separated and sprayed with $1 \mathrm{~mL}$ of fungal suspension at a concentration of $10^{7}$ conidia $\mathrm{mL}^{-1}$ in every treatment, using a micro-atomizer. The control was treated with ADE + A. After fungal application, the masses were transferred and kept in climatic chambers at $27 \pm$ $1{ }^{\circ} \mathrm{C}$ and $70 \pm 10 \% \mathrm{RH}$. The control was treated with $\mathrm{ADE}+\mathrm{A}$. Evaluations were made daily until adults' emergence. The experiment was carried out in a completely randomized design, consisting of 3 treatments with 15 replicates, and every replicate consisted of a cocoon mass. The treatments were: (1) Masses sprayed only with the $M$. anisopliae fungus; (2) Masses sprayed only with B. bassiana fungus; and (3) Control.

The evaluated parameters were the pupal viability and the number of adults. The data were submitted to analysis of variance using the SAS software (SAS, 1999-2001), and the means were compared by a Tukey test $(\mathrm{P}=0.05)$.

Effect of Fungi on Parasitoid Adults. Circular plastic cages $(6.5 \mathrm{~cm}$ diameter $\times 7.5 \mathrm{~cm}$ height $)$ with 2 side openings ( $2.5 \mathrm{~cm}$ diameter), sealed with 'voile' tissue, were internally sprayed with $2 \mathrm{~mL}$ of the fungal suspension at a concentration of $10^{7}$ conidia $\mathrm{mL}^{-1}$ using a micro-atomizer and placed to dry in a laminar flow chamber. Then, 10 oneday-old parasitoid adults were released into every cage and fed with honey applied on the inner side of the cage. Then, the plastic cages were placed in a climate-controlled biological oxygen demand (BOD) chamber at $26 \pm 1{ }^{\circ} \mathrm{C}, 12 \mathrm{~h}$ photoperiod, and $70 \pm 10 \% \mathrm{RH}$. The control was treated with 
$\mathrm{ADE}+\mathrm{A}$. Evaluations were made daily up to the death of adults. The dead insects were transferred to a humid chamber and kept at a temperature of $26 \pm 1{ }^{\circ} \mathrm{C}, 70 \pm 10 \% \mathrm{RH}$, and photophase of 12 hours to confirm the causal agent. The experiment was carried out in a completely randomized design with 3 treatments and 10 replicates; every replicate consisted of 10 adults. The treatments were: (1) Adults sprayed only with the $M$. anisopliae fungus; (2) Adults sprayed only with the $B$. bassiana fungus; and (3) Control.

The evaluated parameters were confirmed mortality, corresponding to mortality caused by fungal colonization, and adult longevity. The data were submitted to analysis of variance using the SAS software (SAS, 1999-2001), and the means were compared by a Tukey test $(\mathrm{P}=0.05)$.

\section{Results and Discussion}

Effect of Fungi on Parasitoid Larvae. The average mortality of $D$. flavipennella caterpillars was $90 \%$ and $87.5 \%$ in treatments with only the application of PL 43 of M. anisopliae and ESALQ 447 of $B$. bassiana, respectively. In treatments in which the caterpillars were subjected only to the parasitoid, the mortality was $72.5 \%$.

Greater mortality of $D$. flavipennella caterpillars was observed in treatments in which both fungi were used than in those in which these agents were applied alone. There was increased mortality in almost all treatments, except when $M$. anisopliae was applied 1 day after the parasitism, which prevented the development of $C$. flavipes. The mortality caused by fungi was reduced in the treatments of 1,3 , and 6 days after the parasitoid inoculation. However, mortality caused by the parasitoid increased over the course of days after spraying the fungi (Table 2). This suggests that the parasitoid and fungi have an inverse relationship over time when used together.

Table 2. Mortality (Mean \pm SE) of Diatraea flavipennella caterpillars parasitized by Cotesia flavipes and sprayed with Metarhizium anisopliae and Beauveria bassiana fungi at a concentration of $10^{7}$ conidia $\mathrm{mL}^{-1}$ in different developmental stages of the parasitoid.

\begin{tabular}{lccc}
\hline \multicolumn{1}{c}{ Treatments $^{1}$} & Fungi & Parasitoid & Total \\
\hline C. flavipes & - & $72.5 \pm 4.78 \mathrm{a}$ & - \\
M. anisopliae & $90.0 \pm 5.77 \mathrm{a}$ & - & - \\
B. bassiana & $87.5 \pm 4.78 \mathrm{ab}$ & - & - \\
M. anisopliae (1 day) & $92.5 \pm 4.33 \mathrm{a}$ & - & - \\
M. anisopliae (3 days) & $90.0 \pm 4.08 \mathrm{ab}$ & $5.0 \pm 2.88 \mathrm{c}$ & $95.0 \pm 2.04 \mathrm{a}$ \\
M. anisopliae (6 days) & $82.5 \pm 7.50 \mathrm{ab}$ & $12.5 \pm 4.78 \mathrm{c}$ & $95.0 \pm 2.04 \mathrm{a}$ \\
B. bassiana (1 day) & $85.0 \pm 6.45 \mathrm{ab}$ & $5.0 \pm 5.00 \mathrm{c}$ & $90.0 \pm 3.74 \mathrm{ab}$ \\
B. bassiana (3 days) & $77.5 \pm 11.08 \mathrm{ab}$ & $22.5 \pm 6.29 \mathrm{bc}$ & $90.0 \pm 3.74 \mathrm{ab}$ \\
B. bassiana (6 days) & $45.0 \pm 5.00 \mathrm{~b}$ & $55.0 \pm 2.88 \mathrm{ab}$ & $92.5 \pm 3.22 \mathrm{a}$ \\
Control & - & - & - \\
\hline
\end{tabular}

${ }^{1}$ Means ( \pm SE) followed by the same letter in a column do not differ among themselves at $5 \%$ by a Tukey test.

Folegatti and Alves (1987) also observed that, with increasing days after inoculation with $C$. flavipes, mortality caused by $M$. anisopliae on D. saccharalis decreased as the mortality caused by parasitoids increased. A similar result was obtained by Rashki et al. (2009) with B. bassiana and Aphidius matricariae Haliday, a parasitoid of Myzus persicae (Sulzer).

Folegatti and Alves (1987) also observed an additive effect from using the 2 agents together, 
except in the treatment with fungus application one day after inoculation with the parasitoid, when the fungus did not allow the parasitoid to develop. Moreover, symptoms of $M$. anisopliae infection in Apanteles flavipes (Cam.) were reported, confirming the results found in this study, i.e., although the parasitoid has completed its development in the host caterpillar, symptoms of $B$. bassiana infection on $C$. flavipes adults were also found.

The mortality caused by M. anisopliae was not affected by the number of days after parasitism when the fungus was applied. B. bassiana caused decreasing mortality, i.e., with increasing days after parasitism, the mortality caused by the fungus was reduced, reaching $37.5 \%$, thus enabling the parasitoid to develop (Table 3). Comparing the mortality caused by the different fungi on different days, it was observed that on the first day, there was no difference among treatments, but $M$. anisopliae had higher mortality rates of $90.0 \%$ on the third day and of $82.5 \%$ on the sixth day than B. bassiana.

Table 3. Mortality (Mean \pm SE) of Diatraea flavipennella caterpillars parasitized by Cotesia flavipes and sprayed with Metarhizium anisopliae and Beauveria bassiana fungi at a concentration of $10^{7}$ conidia $\mathrm{mL}^{-1}$ at different days after parasitism.

\begin{tabular}{lccc}
\hline Days $^{1}$ & M. anisopliae & B. bassiana & Statistics \\
\hline 1 day & $92.5 \pm 2.50 \mathrm{a}$ & $85.0 \pm 8.66 \mathrm{a}$ & $0.83^{0.4584}$ \\
3 days & $90.0 \pm 3.77 \mathrm{a}$ & $67.5 \pm 3.65 \mathrm{a}$ & $4.28^{0.0008}$ \\
6 days & $82.5 \pm 4.53 \mathrm{a}$ & $37.5 \pm 4.50 \mathrm{~b}$ & $7.02^{0.0001}$ \\
\hline Statistics & $\mathrm{F}=1.30^{0.3192}$ & $\mathrm{~F}=23.65^{0.0001}$ & - \\
\hline
\end{tabular}

${ }^{1}$ Means $( \pm \mathrm{SE})$ followed by the same letter in the column do not differ among themselves at $5 \%$ by a Tukey test.

The sex ratio was 0.69 in the treatment in which the caterpillars were submitted only to parasitism. In treatments in which the parasitoid was used with $B$. bassiana, it increased over time, with higher values when the fungus was applied after $3(0.67)$ and 6 (0.68) days of inoculation. In the other treatments, the sex ratio was low, ranging from 0.11 to 0.35 , with a negative effect of the fungi on the parasitoid. A similar effect could be observed in the number of adults in treatments in which the 2 agents were used together; most treatments had reductions, ranging from 6.12 to 36.75 adults, except when $B$. bassiana was applied 6 days after inoculation with the parasitoid (43.98) (Table 4).

Table 4. Sex ratio, number of emerged adults, and average length of egg-adult period (days \pm SE) of Cotesia flavipes parasitizing Diatraea flavipennella caterpillars, which were also sprayed with Metarhizium anisopliae and Beauveria bassiana fungi at a concentration of $10^{7}$ conidia $\mathrm{mL}^{-1}$ at different developmental stages of the parasitoid.

\begin{tabular}{lccc}
\hline Treatments $^{1}$ & Sex ratio & Number of adults & Egg-adult period \\
C. flavipes $_{\text {M. anisopliae (3 days) }}$ & $0.7 \pm 0.02 \mathrm{a}$ & $47.7 \pm 2.68 \mathrm{a}$ & $17.2 \pm 1.30 \mathrm{a}$ \\
M. anisopliae (6 days) & $0.1 \pm 0.01 \mathrm{~b}$ & $6.1 \pm 4.48 \mathrm{c}$ & $18.0 \pm 2.0 \mathrm{ab}$ \\
B. bassiana (1 day) & $0.3 \pm 0.06 \mathrm{ab}$ & $15.2 \pm 9.45 \mathrm{bc}$ & $17.0 \pm 1.58 \mathrm{~b}$ \\
B. bassiana (3 days) & $0.2 \pm 0.11 \mathrm{~b}$ & $8.5 \pm 5.57 \mathrm{c}$ & $24.5 \pm 0.50 \mathrm{a}$ \\
B. bassiana (6 days) & $0.7 \pm 0.11 \mathrm{a}$ & $32.2 \pm 10.20 \mathrm{abc}$ & $16.2 \pm 1.22 \mathrm{~b}$ \\
\hline
\end{tabular}

${ }^{1}$ Means $( \pm \mathrm{SE})$ followed by the same letter in a column do not differ among themselves at $5 \%$ by a Tukey test. 
Regarding the egg-adult period, results showed that fungi could extend the parasitoid development. However, treatment with $B$. bassiana showed no negative effect on the parasitoid development when applied 6 days after parasitoid inoculation, allowing it to complete its cycle.

Effect of Fungi on Parasitoid Pupae. M. anisopliae and B. bassiana did not cause pupal mortality, confirming the results obtained by Folegatti et al. (1990) compared to M. anisopliae. However, a negative effect of fungi on the reduction of pupal viability was observed, mainly by application of $B$. bassiana $(72.20 \%)$. The number of emerged adults was also affected by fungi, with averages of 29.80, 33.20, and 52.20 adults for B. bassiana, M. anisopliae, and the control, respectively (Table 5).

Table 5. Pupae viability and number of adults emerged from Cotesia flavipes pupae after exposure to Metarhizium anisopliae and Beauveria bassiana fungi at a concentration of $10^{7}$ conidia $\mathrm{mL}^{-1}$.

\begin{tabular}{lcc}
\hline Treatments $^{1}$ & Pupal viability & Number of adults \\
\hline B. bassiana & $72.2 \pm 11.54 \mathrm{~b}$ & $29.8 \pm 10.80 \mathrm{~b}$ \\
M. anisopliae & $76.4 \pm 9.91 \mathrm{ab}$ & $33.2 \pm 9.10 \mathrm{~b}$ \\
Control & $89.0 \pm 3.16 \mathrm{a}$ & $52.2 \pm 8.60 \mathrm{a}$ \\
\hline Statistics & $\mathrm{F}=4.75^{0.0303}$ & $\mathrm{~F}=7.89^{0.0065}$ \\
\hline
\end{tabular}

${ }^{1}$ Means $( \pm$ SE) followed by the same letter in a column do not differ among themselves at $5 \%$ by a Tukey test.

Effect of Fungi on Parasitoid Adults. B. bassiana was found to cause high mortality $(76.0 \%)$, unlike M. anisopliae, which showed low adult mortality (9.0\%) (Table 5). This suggests that M. anisopliae would be more suitable for using with $C$. flavipes, since it causes low mortality in endoparasitoid adults, favoring borer control. Folegatti et al. (1990), when evaluating the pathogenicity of $M$. anisopliae on A. flavipes adults, found that this fungus caused low mortality. Similar results were obtained by Hayashida et al. (2012), who found low pathogenicity when testing higher concentrations of M. anisopliae on C. flavipes adults.

Regarding the longevity of adults, no effect of fungi was observed, because the adult lifetimes of survivors in treatments with fungi did not differ from the control (Table 6).

Table 6. Mortality (Mean \pm SE) and longevity of Cotesia flavipes adults after exposure to Beauveria bassiana and Metarhizium anisopliae fungi at a concentration of $10^{7}$ conidia $\mathrm{mL}^{-1}$.

\begin{tabular}{lcc}
\hline Treatments $^{1}$ & Mortality & Longevity \\
\hline B. bassiana & $76.0 \pm 2.91 \mathrm{a}$ & $4.7 \pm 0.83 \mathrm{a}$ \\
M. anisopliae & $9.0 \pm 6.0 \mathrm{~b}$ & $4.8 \pm 0.44 \mathrm{a}$ \\
Control & - & $4.6 \pm 1.08 \mathrm{a}$ \\
\hline Statistics & $\mathrm{F}=10.040001$ & $\mathrm{~F}=0.070 .9307$ \\
\hline
\end{tabular}

${ }^{1}$ Means $( \pm \mathrm{SE})$ followed by the same letter in a column do not differ among themselves at $5 \%$ by a Tukey test. 


\section{Conclusions}

The ESALQ 447 and PL 43 isolates of $B$. bassiana and $M$. anisopliae, respectively, have no negative effect on the larval stage of $C$. flavipes parasitizing D. flavipennella caterpillars. They also are not pathogenic to $C$. flavipes pupae. However, $B$. bassiana cause high mortality in adults. Nevertheless, fungi can cause mortality when applied in certain stages of parasitoid development, necessitating further studies to determine the most appropriate time for using it in integrated pest management programs for sugarcane pests.

\section{References}

ALVES, S. B.; LOPES, R. B. Controle microbiano de pragas na América Latina: avanços e desafios. Piracicaba: FEALQ, 2008. 414 p.

ALVES, S. B.; LOPES, R. B.; VIEIRA, S. A.; TAMAI, M. A. Fungos Entomopatogênicos usados no controle de pragas na América Latina. In: ALVES, S. B.; LOPES, R. B. (Ed.). Controle microbiano de pragas na América Latina: avanços e desafios. Piracicaba: FEALQ, 2008. p. 69-110.

COMPANHIA NACIONAL DE ABASTECIMENTO - CONAB. Safra da cana-de-açúcar. Brasília: CONAB, 2014. Disponível em: <http://www.conab.gov.br/ conteudos.php? $\mathrm{a}=1253 \& \mathrm{t}=>$. Acesso em: 12 set. 2014.

FOLEGATTI, M. E. G.; ALVES, S. B. Interação entre o fungo Metarhizium anisopliae (Metsch.) Sorok., e os principais parasitóides da broca da cana-de-açúcar, Diatraea saccharalis (Fabricius, 1794). Anais da Sociedade Entomológica do Brasil, Londrina, v. 16, n. 2, p. 351-362, 1987.

FOLEGATTI, M. E. G.; ALVES, S. B.; BOTELHO, P. S. M. Patogenicidade do fungo Metarhizium anisopliae (Metsch.) Sorok. para pupas e adultos de Apanteles flavipes (Cam.). Pesquisa Agropecuária, Brasília, v. 25, n. 2, p. 247-251, 1990.

FREITAS, M. R. T.; FONSECA, A. P. P.; SILVA, E. L.; MENDONÇA, A. L.; SILVA, C. E.; MENDONÇA, A. L.; NASCIMENTO, R. R.; SANT'ANA, A. E. G. The predominance of Diatraea flavipennella (Lepidoptera: Crambidae) in sugar cane fields in the State of Alagoas, Brazil. Florida Entomologist, Lutz, v. 89, n. 4, p. 539540, 2006.
FREITAS, M. R. T.; SILVA, E. L.; MENDONÇA, A. L.; SILVA, C. E.; FONSECA, A. P. P.; MENDONÇA, A. L.; SANTOS, J. S.; NASCIMENTO, R. R.; SANT'ANA, A. E. G. The biology of Diatraea flavipennella (Lepidoptera: Crambidae) reared under laboratory conditions. Florida Entomologist, Lutz, v. 90, n. 2, p. 309-313, 2007.

HAYASHIDA, E. K.; KASSAB, S. O.; FONSECA, P. R. B.; ROSSONI, C.; LOUREIRO, E. S.; AMORIM, L. G. P. Efeito dos isolados de Metarhizium anisopliae (Metschnikoff) Sorokin (Hypocreales: Clavicipitaceae) sobre parasitoide Cotesia flavipes (Cameron, 1891) (Hymenoptera: Braconidae). Nucleus, Ituverava, v. 9, n. 1, p. 73-78, 2012.

MAGALHÃES, B. P.; MONNERAT, R.; ALVES, S. B. Interações entre entomopatógenos, parasitóides e predadores. In: ALVES, S. B. (Ed.). Controle microbiano de insetos. Piracicaba: FEALQ, 1998. p. 195-216.

PINTO, A. S.; GARCIA, J. F.; BOTELHO, P. S. M. Controle biológico de pragas da cana-de-açúcar. In: PINTO, A. S.; NAVA, D. E.; ROSSI, M. M.; MALERBOSOUZA, D. T. (Org.). Controle biológico de pragas: na prática. Piracicaba: FEALQ, 2006. p. 65-74.

RASHKI, M.; KHARAZI-PADKDEL,A.;ALLAHYARI, H.; VAN ALPHEN, J. J. M. Interactions among the entomopathogenic fungus, Beauveria bassiana (Ascomycota:Hypocreales), the parasitoid, Aphidius matricariae (Hymenoptera: Braconidae), and its host, Myzus persicae (Homoptera: Aphididae). Biological Control, Orlando, v. 50, n. 3, p. 324-328, 2009.

ROSSI-ZALAF, L. S.; ALVES, S. B.; LOPES, R. B.; SILVEIRA NETO, S.; TANZINI, M. R. Interações de micorganismos com outros agentes de controle de pragas e doenças. In: ALVES, S. B.; LOPES, R. B. (Ed.). Controle microbiano de pragas na América latina: avanços e desafios. Piracicaba: FEALQ, 2008. p. 270302.

SATISTICAL ANALYSES SYSTEM - SAS. SAS/STAT 1999-2001 User's guide: statistics. Cary, version 8, v. 2, 1999-2001.

WHITE, W. H.; VIATOR, R. P.; DUFRENE, E. O.; DALLEY, C. D.; RICHARD JÚNIOR, E. P.; TEW, T. L. Reevaluation of sugarcane borer (Lepidoptera: Crambidae) bioeconomics in Louisiana. Crop Protection, Lincoln, v. 27, n. 9, p. 1256-1261, 2008. 
